\title{
Prevalence of gastrointestinal helminths in Mithun in Arunachal Pradesh
}

\author{
S. Biswas ${ }^{1}$, M. N. Tigga² ${ }^{2}$ R. K. Bauri² and P. Biswas ${ }^{3}$
}

1. Division of Medicine, Indian Veterinary Research Institute, Izatnagar, Bareilly, Uttar Pradesh, India; 2. Division of Veterinary Parasitology, Indian Veterinary Research Institute, Izatnagar, Bareilly, Uttar Pradesh, India; 3. Division of Livestock Production and Management, Indian Veterinary Research Institute, Izatnagar, Bareilly, Uttar Pradesh, India. Corresponding author: R. K. Bauri, e-mail: drrkbauri@gmail.com, SB: sumanvet.09@gmail.com, MNT: marynisha28@gmail.com, PB: prabhakarvet@gmail.com

Received: 05-07-2014, Revised: 12-09-2014, Accepted: 17-09-2014, Published online: 20-10-2014

doi: 10.14202/vetworld.2014.856-858. How to cite this article: Biswas S, Tigga MN, Bauri RK, Biswas P (2014) Prevalence of gastrointestinal helminths in Mithun in Arunachal Pradesh, Veterinary World 7(10): 856-858.

\begin{abstract}
Aim: The objective of this study was to know the prevalence of gastrointestinal (GI) parasites in Mithun in Arunachal Pradesh.

Materials and Methods: Approximately, $10 \mathrm{~g}$ of feces was collected from recently voided feces in airtight fecal collection vials (HiMedia, India). Fecal samples were subjected to the direct method and centrifuge flotation method for finding out parasitic ova. The ova were identified on the basis of morphological characters described by Soulsby, 1982.

Result: A total of 78 fecal samples were collected. Of 78, 44 (56.41\%) samples were found positive. Most of the positive fecal sample showed mixed infection of different helminths parasites egg. Fasciola spp. and Amphistome spp. were the two predominant parasites among the flukes. In nematodes infection, Toxocara vitulorum was the least prevalent GI nematodes. In the case of cestodes Moniezia expansa was little higher (14\%) in semi-intensive.

Conclusion: The present study reveals that Mithun is infected by several GI parasites. Among trematodes, Fasciola, and Amphistomes are predominantly spp. whereas, Strongyle and Trichuris are more prevalent spp. among nematodes and Moniezia among cestodes parasites.
\end{abstract}

Keywords: Arunachal Pradesh, gastrointestinal helminths, Mithun.

\section{Introduction}

Bos frontalis also known as Mithun, a "Cattle of Hilly Region” [1] is a unique exotic ruminant found in the hill region of northeast India, Myanmar, Bhutan, Bangladesh, China, and Malaysia [2]. In India, semi-domesticated $B$. frontalis are kept by several ethnic groups living in the hills of Tripura, Mizoram, Assam, and Arunachal Pradesh. They also occur in the Chittagong hill tracts [3]. In northern Myanmar, they occur in the Kachin State, and in the adjacent Yunnan province are found only in the Dulong and Nujiang River basins [4]. In India, there are four distinct strains of Mithun, i.e., Arunachal strain, Manipur strain, Mizoram strain, and Nagaland strain. This prized hill animal of the North-Eastern Hill Region has an important role in the economic, social, cultural, and religious life of the local tribal population who inhabit the area [5]. This animal is basically raised as ceremonial animal and used to be sacrifice for meat during festival and social ceremonies by tribal people. Tribal people also use for bridal gift and in barter trade. The animal is reared by the tribal only in the hilly regions mainly for meat purposes and is considered as a sign of prosperity and superiority of an individual in the tribal society of the state. The animals

Copyright: The authors. This article is an open access article licensed under the terms of the Creative Commons Attributin License (http:// creative commons.org/licenses/by/2.0) which permits unrestricted use, distribution and reproduction in any medium, provided the work is properly cited. are sacrificed in the marriage ceremonies, religious function or a big feast.

The currency value of Mithun varies from one region to other; it is spoken as currency due to their being present in the value system and being used in exchange of land. Mithun is also employing in payment for ransom, tribute, fine or bride price. Like other animals, mithuns also suffers from bacterial, viral and parasitic diseases [2,6-10]. Twelve nematode genera, viz. Trichuris, Capillaria, Strongyloides, Toxocara, Ascaris, Oesophagostomum, Bunostomum, Mecistocirrus; Cooperia ostertagia, Thelazia and Dictyocaulus, four trematodes, viz. Fasciola, Gastrodiscoides, Gastrothylax and Paramphistomum; and two cestodes, Moniezia and Taenia spp. were reported in Mithun in Arunachal Pradesh and Bhutan [11]. Gastrointestinal parasitic infections in Mithuns have been reported to cause mortality and morbidity [12].

The main aim of the study was to highlight the different helminth parasites harboured by Mithun in north eastern region of country.

\section{Materials and Methods}

\section{Ethical approval}

Not necessary.

\section{Study area}

Arunachal Pradesh (Figure-1) is located between $26.28^{\circ} \mathrm{N}$ and $29.30^{\circ} \mathrm{N}$ latitude and $91.20^{\circ} \mathrm{E}$ and $97.30^{\circ} \mathrm{E}$ longitude and has $83,743 \mathrm{~km}^{2}$ area. The climate of Arunachal Pradesh varies with elevation. 


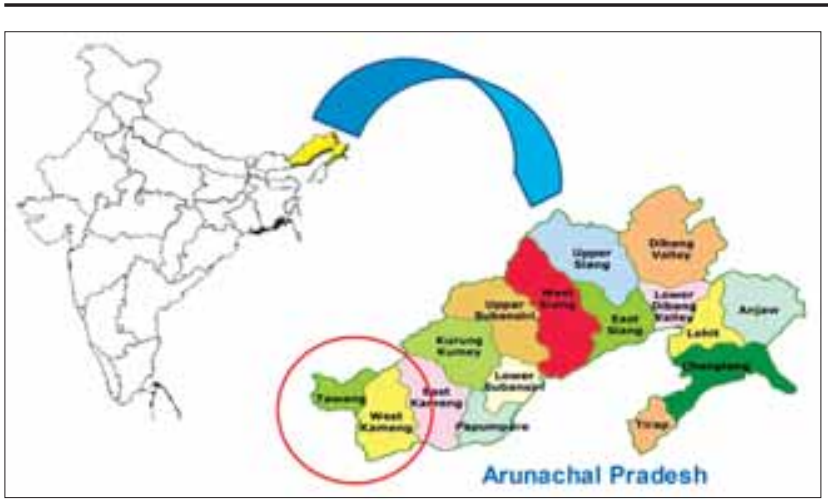

Figure-1: Study area in Arunachal Pradesh.

Areas that are at a very high elevation in the upper Himalaya close to the Tibetan border have an alpine or tundra climate. Below the upper Himalayas are the middle Himalayas, where people experience a temperate climate. Areas at the sub-Himalayan and sealevel elevation generally experience humid, sub-tropical climate with hot summers and mild winters. Arunachal Pradesh receives heavy rainfall of 2,000$4,100 \mathrm{~mm}$ (79-161 in) annually, most of it between May and September.

\section{Collection of fecal sample}

Randomly, 78 fecal samples were collected, of which 38 from free-ranging Mithun and 40 from semi-intensive Mithun. All animals were sexually mature and seem to be healthy as per owner history or herd handlers. Approximately, $10 \mathrm{~g}$ of feces was collected from recently voided feces in airtight fecal collection vials (HiMedia, India) individually. Then individual fecal samples were brought to the laboratory for examination. The samples were examined by centrifugation and floatation method as described by Soulsby [13]. The endoparasites, ova or oocyst, were identified based on morphological characters described by Soulsby [13].

\section{Statistical analysis}

Raw data were entered into a Microsoft Excel spreadsheet, and descriptive statistics were used to summarize the data. The prevalence was calculated for all data as the number of infected individuals divided by the number of individuals examined and multiplied by 100 to express in percentage. Chi-square was used to assess the association of risk factors on the prevalence of parasites.

\section{Result}

A total of 78 fecal samples was examined for ova of different helminth parasites. In which 44 (56.41\%) samples were found positive for different parasitic ova. All positive samples showed mixed infection containing more than one parasitic egg. The Strongyle spp. was predominant with 44 (56.41\%) followed by Amphistome spp. 40 (51.28\%), Moniezia expansa 25 (32.05\%), Moniezia benedeni 17 (21.79), Fasciola spp. 15 (19.23\%), Trichuris spp. 7 (8.94\%), and Toxocara vitulorum $2.63 \%$ (Table-1).
Table-1: Prevalence of different helminth parasites in Mithun.

\begin{tabular}{|c|c|c|c|c|}
\hline $\begin{array}{l}\text { Name of } \\
\text { parasite }\end{array}$ & $\begin{array}{c}\text { Free } \\
\text { ranging } \\
(\mathbf{n}=38)\end{array}$ & $\begin{array}{c}\text { Semi } \\
\text { intensive } \\
(n=40)\end{array}$ & Total & $\chi^{2}$ value \\
\hline \multicolumn{5}{|l|}{ Flukes } \\
\hline $\begin{array}{l}\text { Fasciola } \\
\text { spp. }\end{array}$ & $11(28.94)$ & $4(10)$ & $15(19.23)$ & $4.50 *$ \\
\hline $\begin{array}{l}\text { Amphistome } \\
\text { spp. }\end{array}$ & $22(57.89)$ & $18(45)$ & $40(51.28)$ & 1.297 \\
\hline \multicolumn{5}{|c|}{ GI nematodes } \\
\hline $\begin{array}{l}\text { Strongyle } \\
\text { spp. }\end{array}$ & $26(68.42)$ & $18(45)$ & $44(56.41)$ & $4.34 *$ \\
\hline Trichuris spr & $2(5)$. & $5(12.5)$ & $7(8$. & 1.24 \\
\hline T. vitulorum & $1(2.63)$ & 0 & $1(2.63)$ & - \\
\hline \multicolumn{5}{|l|}{ Cestodes } \\
\hline M. expansa & $9(2$ & $14(35)$ & 23( & 1.20 \\
\hline M. benedini & $6(15.78)$ & $11(27.5)$ & $17(21.79)$ & 1.56 \\
\hline
\end{tabular}

T. vitulorum=Toxocara vitulorum, M. expansa=Moniezia expansa, $M$. benedeni=Moniezia benedeni,

$\mathrm{Gl}=$ Gastrointestinal * significant at $5 \%$ level of significance

The present study also indicated that in free-ranging condition Strongyle spp. was the most prevalent with 26 (56.41\%), followed by Amphistome spp. 22 (57.89), Fasciola spp.11 (28.94), M. expansa 9 (23.68), and $M$. benedeni 6 (15.78) whereas, Trichuris and T. vitulorum were less prevalent with $5.26 \%$ and $2.63 \%$, respectively. In semi-intensive condition, Strongyle and Amphistomes were predominant with $45 \%$ followed by $M$. expansa and $M$. benedeni with $35 \%$ and $27.5 \%$, respectively. No samples were found positive for $T$. vitulorum semi-intensive condition (Table-1). Chi-square value revealed that there is significant difference $(\mathrm{p}=0.05)$ in Fasciola spp. and Strongyle infection in free-ranging and semi intenstive system. Free ranging system showed significantly higher in infection than semi-intensive system.

\section{Discussion}

In our study, the overall prevalence of different helminth parasites is $56.41 \%$. Rajkhowa et al., [8] reported similar prevalence rate $55.60 \%$ in Arunachal Pradesh but prevalence rate was higher in Nagaland were found to be $100 \%$ infected followed Mizoram (66.70\%), and Manipur (60.00\%). In the present study, most reported helminth parasite of Mithun are Strongyles spp., Amphistomes spp., Fasciola spp., M. expansa, and M. benedeni. Chamuah et al., [9] and Tandon et al., [11] also reported these parasites are common in Mithun. In our study, Strongyles are predominant spp. Rajkhowa et al., [8] also reported similar findings with the prevalence rate of $54.05 \%$. In our study, there is slightly less prevalence rate of Strongyle, Amphistomes, Fasciola, and T. vitulorum in semi-intensive condition with comparison of free-ranging condition. Laha et al., [14] also reported that prevalence rate is relatively low of Strongyle and other parasitic infection in organized farm. 


\section{Conclusion}

The present study reveals that Mithun is infected by several GI parasites. Among trematodes, Fasciola, and Amphistomes are predominantly spp. whereas, Strongyle and Trichuris are more prevalent spp. among nematodes and Moniezia among cestodes parasites.

\section{Authors' Contributions}

SB and PB design the work, SB carried out the work. RKB helped in manuscript preparation; RKB and MNT collected materials for manuscript. SB collected samples. All authors read and approved the final manuscript.

\section{Acknowledgments}

The authors are thankful to the farmers and all local veterinarian of different region of Arunachal Pradesh. The work was carried out using the institutional fund provided by the University.

\section{Competing I nterests}

The authors declare that they have no competing interests.

\section{References}

1. Shisode, M.G., Khanvilkar, A.V., Kulkarni, M.D., Samant, S.R., Yadav, G.B. and Bawaskar, M.S. (2009) Mithun: The pride animal of North-Eastern hilly region of India. Vet. World, 2: 480-481.

2. Rajkhowa, S., Rajkhowa, C., Rahman, H. and Bujabaruah, K.M. (2004) Sero-prevalence of infectious bovine rhinotracheitis in Mithun in India. Rev. Sci. Tech., 23: 821-829.
3. Simoons, F.J. (1984) Gayal or Mithun. In: Mason, I.L. editor. Evolution of Domesticated Animals. Longman, London. p34-38.

4. $\quad$ Lydekker, R. (1888-1890) The New Natural History. Vol. 2. Printed by Order of the Trustees of the British Museum (Natural History), London. p179-181.

5. NRCM. (2010) National Research Centre on Mithun, Jharnapani, Medziphema, Nagaland, India. http://www. nrcmithun.res.in. Last accessed on 04-09-2014.

6. Rajkhowa, S., Rajkhowa, C. and Bujarbaruah, K.M. (2003) Diseases of Mithun (Bos frontalis) - A review. Vet. Bull., 73: 1R-6R.

7. Rajkhowa, S., Bujarbaruah, K.M., Rajkhowa, C. and Kapenlo, T. (2004) Incidence of intestinal parasitism in Mithun (Bos frontalis). J. Vet. Parasitol., 19: 39-41.

8. Rajkhowa, S., Bujarbaruah, K.M, Rajkhowa, C. and Kapenlo, T. (2005) Incidence of intestinal parasitism in Mithun (Bos frontalis). J. Vet. Parasitol., 19: 39-41.

9. Chamuah, J.K., Das, M., Islam, S., Rajkhowa, C. and Chakraborty, A. (2009) Studies on naturally acquired gastrointestinal helminth of Mithun (Bos frontalis). J. Vet. Parasitol., 23: 37-40.

10. Chamuah, J.K., Das, M., Rajkhowa, S., Islam, S. and Rajkhowa, C. (2009) Coccidiosis in Mithun (Bos frontalis). Indian Vet. J., 86: 419-420.

11. Tandon, V., Kar, P. K., Das, B., Sharma, B. and Dorjee, J. (2005) Preliminary survey of gastro-intestinal helminth infection in herbivorous livestock of mountainous regions of Bhutan and Arunachal Pradesh. Zoos' Print J., 20(5): 1867-1868.

12. Chamuah, J.K., Perumal, P., Singh, V., Mech, A. and Borkotoky, D. (2013) Helminth parasites of Mithun (Bos frontalis) - An overview. Indian J. Anim. Sci., 83: 235-237.

13. Soulsby, E.J.L. (1982) Helminths, arthropods and protozoa of domesticated animals. $7^{\text {th }}$ ed. (ELBS) Bailiere Toindal, London.

14. Laha, R., Rajkhowa, C., Chamuah, J.K. and Goswami, A. (2013) Gastrointestinal parasitic infections in Mithun in organised farm. Indian J. Hill. Forming, 26(1): 45-46. 